\title{
A Think-Aloud Study: Listening Comprehension Strategies Used by Primary School Students ${ }^{*}$
}

\author{
Berker Bulut $^{1}$, İhsan Seyit Ertem ${ }^{2}$ \\ ${ }^{1}$ Faculty of Education, Adnan Menderes University, Aydın, Turkey \\ ${ }^{2}$ Gazi Faculty of Education, Gazi University, Ankara, Turkey \\ Correspondence: Berker Bulut, Faculty of Education, Adnan Menderes University, Aydın, Turkey.
}

Received: February 26, 2018

Accepted: March 26, $2018 \quad$ Online Published: April 9, 2018

doi:10.11114/jets.v6i5.3050

URL: https://doi.org/10.11114/jets.v6i5.3050

\begin{abstract}
The purpose of this research is describing and comparing the listening-comprehension strategies used by the students who are identified as successful and less successful about listening. In the research, the case study pattern was used among the qualitative research approaches. In the study, different situations of each student within the same group were examined. The study was carried out in 2017 with four students who attend the fourth grade of the primary school at the middle socioeconomic level in Efeler district of Aydın city. The data related to the cognitive processes used by the students who are selected using sampling of maximum diversity from purposeful sampling methods, during listening were obtained through the method of think aloud, which is one of the utmost effective ways of describing the cognitive activities in the listening comprehension process and of the comprehension strategies used in this process. When the data obtained from the think-aloud method was interpreted, it has been observed that the listening-comprehension strategies used by students differed. It has been determined that students who are identified as successful listener use more strategies on their listening comprehension process. Consequently, it is possible to state that the students are unaware of using the listening comprehension strategies since they are very little. It was also concluded that students who were identified as both successful and unsuccessful listeners have reached less the level of evaluation in terms of strategies.
\end{abstract}

Keywords: think-aloud, listening, comprehension, strategy, primary school students

\section{Introduction}

Unlike hearing, listening is a physical and a mental process, which requires both attention to the source of the sound and need to make sense of the voices heard. According to Ergin and Birol (2000, p. 15), listening is a psychological process which starts with being aware of sounds and images and paying attention to them, continues with the recognition of certain auditory signs and ends with meaning Accordingly, it can be said that listening is a conscious process that requires effort. As Umagan (2007, p. 149) has stated, listening is not following the other side in a passive way; it is an effort to receive and interpret the message in order for the communication to be fully realized.

Onan (2005) describes the process of comprehension by listening as the listener's distinguishing of the ones with linguistic quality in the incoming groups of phones and then his or her ability to initiate the feedback process by having these groups of phones with linguistic quality subjected to a mental process. In this sense, understanding what is listened to is not just about hearing what is said but also about giving importance to what is said, understanding and evaluating it. In this respect, in order for students to understand what they are listening to and to structure it in their mind, they should be asked to do following activities: visualizing what they listen to, researching the meaning of the words they do not know, determining the main idea, topic, classifying and questioning what they listen to, establishing relationships and making inferences about it, estimating the outcome, summarizing, evaluating it and sharing it with their friends.

\footnotetext{
*This study is generated from doctoral dissertation titled "Investigation of the Listening and Reading Comprehension Skills of Primary School Students in Terms of Cognitive Processes" prepared by Berker BULUT by the supervision of the second writer.
} 
It should be taken into account that listening is a process containing a range of preferences rather than a momentary situation that begins and ends at an instant. In this process, the right choices help listeners in the listening process while the wrong choices make it difficult for listeners to make sense (Tüzel, 2013). It has been stated by the field experts that the learners who use listening strategies understand the differences in the text they listen to more quickly and correctly ( $\mathrm{Su}, 2002)$; there is a positive correlation between strategy use and student performance (Bialystok, 1981); using the right strategy affects the performance of the student (O’Malley, Chamot and Kupper, 1989).

A listener can think four times faster than the normal speaker. The ability to use this advantage depends on the intertextual listening. It means that students guess what the teacher will tell next in the classroom environment, they summarize what has been told, silently question the teachings and transform what they have listened into their own thinking (Akyol, 2010, p. 6). It is important to determine whether the learner is effectively using the mentioned activities. In this sense, in order to determine these strategies used in the listening process, the method of thinking out loud can be used as a tool. Güneş (2012) emphasizes that the purpose of the think-aloud method is to clarify the cognitive operations, processes, and thoughts used during an activity. The method of think-aloud, which is often used in reading comprehension studies, is also an appropriate method for listening studies that constitute the other dimension of the understanding process. In the method of think-aloud, readers need to explain what they understand and think while they are reading the text aloud, taking breaks in predetermined sections. In this way, the reader's verbal reports are recorded, and the information is obtained on how they understand the text and how they solve the comprehension challenges they encounter. Similarly, in this study, after listening to a certain part of the text a pause was made and primary school students were expected to express what they understand from what they have listened to and to think out loud about what they think about the relevant chapter. Thus, using the method of thinking out loud facilitated the determination of the strategies students use in understanding the text during listening. Thusly Someren, Barnard, and Sandberg $(1994$, p. 30) explain two reasons why the think-aloud method is better than other verbal data collection methods as follows:

$>$ The method of think-aloud avoids the interpretation made by the persons and includes a verbal expression process consisting of simple words.

$>$ The method of think-aloud treats the verbal protocols as data that appeals to everybody and thus, forms an objective method.

\subsection{The Purpose of the Research}

In this study, it is aimed to describe and compare the comprehension strategies used by the students who are identified as successful and less successful about listening by using the think-aloud method. In line with this main purpose, the problem statement is as follows; "What strategies that the fourth-grade students of the primary school use for comprehending while listening and how they use these strategies?". In order to obtain richer and deeper knowledge about the research process, the answers to following sub-problems were also searched:

1. Which comprehension strategies do primary school fourth-grade students use in their listening comprehension process?

2. Do the understanding strategies used by the fourth-grade students in the listening comprehension process vary according to the type of the text?

3. Do the understanding strategies used by the fourth-grade students in the listening comprehension process vary according to the listening profile?

\section{Method}

\subsection{Research Model}

In the research, the case study pattern was used among the qualitative research approaches. Case study in qualitative research is to try to understand the activities that a situation which is different from the others is realized in its own special conditions (Stake, 1995). In this study, various cases of each student within the same group were examined. On the other hand, case studies involve in-depth study of data obtained and analyzed through participant observations, in-depth interviews, and document collection (Glesne, 2011). In the study, the thinking aloud method, which provided in-depth interviewing, was used as a method of the case study. The verbal information obtained by this method, in which participants spoke verbally about passing through their minds while listening, provided the determining of the listening comprehension strategies.

\subsection{Study Group}

In this study, maximum diversity sampling was used from purposeful sampling methods. The main aim of this sampling is to reach a richer knowledge about a situation. It is stated that this method has benefits in terms of detailed description 
of the specific dimensions of the situation within the sample and revealing common themes between situations with different characteristics (Patton, 2002). In order to provide diversity in this study, similar situations in itself, such as listening success, gender, socio-economic level, were determined and according to these cases a study group has been established. For this purpose, firstly, as of the academic year 2016-2017, a school that was at a moderate socioeconomic level and that would not show any contradiction was determined in Efeler town of Aydin province. Then, in order to choose the students that would participate in the practice, "Listening Comprehension Test", developed by the researcher, was applied. The tests were presented on different days during one lesson to 144 students studying in five classes. As a result of the tests, students were separated into low and high score groups in terms of listening comprehension success. In order to provide diversity, one girl and one male from each group and students from different socioeconomic levels were selected. The selection of students has also taken into consideration the fact that they have personal characteristics such as being able to express themselves and being extroverted. No student was forced by the researcher or their teachers to participate in the study. We also paid attention that there was no mental disability obstacle of students in learning while identifying the participants. Information was obtained from the class teacher and school counselor as to whether there was an obstacle of the student. Thus, the information of the students participating in the survey is given in table below.

Table 1. Information on Students Attending the Survey

\begin{tabular}{|c|c|c|c|}
\hline Students & Gender & Listening Level & Listening Profile \\
\hline S1 & Girl & Successful Listener & She follows the rules about listening carefully to her teacher. \\
\hline S2 & Boy & Successful Listener & $\begin{array}{l}\text { He shows the behavior of notifying his opinion without interrupting his friends' } \\
\text { speech. }\end{array}$ \\
\hline S3 & Girl & $\begin{array}{l}\text { Unsuccessful } \\
\text { Listener }\end{array}$ & $\begin{array}{l}\text { She doesn't take the floor in the lesson and despite she is silent she doesn't pay } \\
\text { attention to course. }\end{array}$ \\
\hline S4 & Boy & $\begin{array}{l}\text { Unsuccessful } \\
\text { Listener }\end{array}$ & $\begin{array}{l}\text { He behaves contrary to the rules of listening in the lesson, such as talk aloud without } \\
\text { permission, dealing with a thing. }\end{array}$ \\
\hline
\end{tabular}

\subsection{Data Collection Tools}

\subsubsection{Listening Comprehension Test}

In order to measure the achievement of the students' listening comprehension, the "Listening Comprehension Test" was developed by the researcher. While the test was being prepared, the test went through the following steps.

1. First of all, in accordance with the aim of the research, the measurable ones among the five acquisitions related to the listening comprehension about the fourth grade listening learning field was selected. For this purpose, two academicians each from Turkish Education, Education Programmes and Teaching Test and Evaluation in Education were interviewed and their ideas about the subject were gathered. As a result of the assessments made, it was concluded that of the listening comprehension acquisitions, four acquisitions had measurable characteristics.

2. Once the acquisitions were determined, text selection was made. In accordance with this purpose, besides reading books prepared for elementary school students, the listening texts in Turkish textbooks, which have been approved as an appropriate course book for the level of fourth-grade students, were selected. After that, the selected texts were evaluated by 5 faculty members, who are experts in the field of Primary Education. The experts evaluated texts according to the criteria of the contents' comprehensibility by students and the level of the words in the text. Consequently, the contents of the informative texts for listening were deemed to be difficult, so they were not found appropriate. Also, due to the fact that students had more experience with listening texts, the author Ann Donegan Johnson's reading book "The Importance of Being Fair - The Story of Nellie Bly" was chosen. The content of the book was shortened being edited by the researcher and was used for the test as listening text with the title "Seeking the Right".

3. Take into account the acquisitions determined, questions in terms of each acquisition were included to be able to provide the content validity and a question pool of totally 30 items was formed. While preparing the questions, evaluation approaches of the exams with international scale were used (PIRLS, 2001; PISA, 2009; PISA, 2012). Based on this, 30 items in the pool of questions were examined by one faculty number in the Field of Measurement and Evaluation in Education and three faculty members in the field of Primary Education in terms of suitability of the questions to the acquisition, suitability of the questions to the level of students and question writing technique. The items not found suitable for the test were removed by the experts, after some adjustments were made on some items, they were added to the trial form. Consequently, a trial form consisting of 22 items was prepared.

4. The trial form was applied to a total of 205 students studying at the fourth grade of three schools with similar characteristics to the schools in which the application would be implemented. The students were asked to answer all questions seriously, to express the questions they had difficulty in understanding, and they were given enough time to answer. 
5. After the trial practices, item and test analyzes were performed. As a result of the statistical procedures for the item analysis, the difficulty index, standard deviation and discriminant index values of the items in the test were calculated. Items with a discrimination index of less than .30 were eliminated. As a result of these analyzes, the Listening Comprehension Test consisting of 19 items was prepared.

6. The t-test results for the difficulty index, standard deviation and discriminant index values of the final form of the test items and the lower and upper 27\% groups are given in Table 2 below.

Table 2. Item Analysis Results of the Listening Comprehension Test

\begin{tabular}{|c|c|c|c|c|}
\hline Items & Difficulty Indeks ${ }^{1}$ & Standart Deviation $^{1}$ & Discriminant Indeks ${ }^{1}$ & T (Lower \%27- Upper \%27) \\
\hline 1.1 & .60 & .48 & .53 & $15.58^{* * * *}$ \\
\hline 1.2 & .61 & .48 & .53 & $15.60^{* * * *}$ \\
\hline 2.1 & .94 & .23 & .48 & $3.46^{* * * *}$ \\
\hline 2.2 & .75 & .43 & .42 & $5.61^{\text {**** }}$ \\
\hline 2.3 & .90 & .29 & .51 & $4.02^{* * *}$ \\
\hline 2.4 & .94 & .23 & .51 & $3.67^{* * * *}$ \\
\hline 2.5 & .82 & .38 & .45 & $6.23^{* * * *}$ \\
\hline 2.6 & .90 & .29 & .55 & $5.12^{* * *}$ \\
\hline 2.7 & .77 & .41 & .57 & $9.00^{* * * *}$ \\
\hline 2.8 & .72 & .44 & .53 & $9.08^{* * *}$ \\
\hline 2.9 & .51 & .50 & .45 & $11.69^{* * *}$ \\
\hline 2.10 & .49 & .50 & .47 & $13.91^{* * * * *}$ \\
\hline 3.1 & .63 & .48 & .41 & $7.77^{* * * *}$ \\
\hline 3.2 & .65 & .47 & .48 & $10.99^{* * * *}$ \\
\hline 5 & .62 & .48 & .43 & $9.47^{* * * *}$ \\
\hline 6 & .83 & .36 & .32 & $5.12^{* * * *}$ \\
\hline 7 & .76 & .42 & .42 & $6.85^{* * *}$ \\
\hline 9 & .42 & .49 & .31 & $7.86^{* * *}$ \\
\hline 10 & .78 & .41 & .44 & $7.76^{* * * *}$ \\
\hline
\end{tabular}

When the table is analyzed, it can be seen that the discriminant power of the 19 items remaining after the items whose discriminant indexes was less than .30 (3.3-8) were removed from the test varied between .31 and .57 and that $t$ value calculated for the lower and upper $27 \%$ groups is significant $(\mathrm{p}<.001)$. These results can be interpreted as that the validity of the items in the test is high and they can distinguish students in terms of listening comprehension achievement.

The results of the test analysis performed after the item analysis are shown in Table 3.

Table 3. Test Analysis Results of Listening Comprehension Test

\begin{tabular}{llllllll}
\hline Total Number of Items & $\mathbf{N}$ & $\mathbf{X}$ & SD & Mode & Median & Mean Difficulty & Cronbach-Alfa $(\boldsymbol{\alpha})$ \\
\hline 19 & 205 & 13.73 & 4.26 & 15 & 15 & .72 & .858
\end{tabular}

When the table is analyzed, it is seen that the mean difficulty of the test scores is .72. Also, it has been concluded that arithmetic mean, mode, and median values are close to each other. According to this, it can be concluded that the test has a distribution close to normal. On the other hand, when we look at the table, it is seen that Cronbach-Alpha internal consistency coefficient, providing information on the reliability of the test, is 858 . This result is higher than 70 , the critical value of for the reliability coefficient, (Kline, 1986; DeVellis, 2003) and it can be interpreted that the test scores are reliable.

\subsubsection{Listening Texts}

Two listening texts, one informative and one narrative, were utilized in the study. The texts included in the scope of the research were selected in accordance with the level of the students attending the fourth grade, from books approved by the Turkish Education Board in accordance with the Elementary Program for Turkish. To determine if the selected texts are appropriate for the fourth grade level of primary school students, two instructors specialized in Turkish Education and Primary Education evaluated in terms of word count, sentence length, language and expression as well as features. The subject area experts expressed their views on the evaluation form prepared for each text. Among the texts, the evaluators gave the score "2" for the ones suitable for the criteria of word count, sentence length, language and narration, "1" for the slightly suitable ones and scores " 0 " for the unsuitable ones. The Krippendorf alpha coefficient was calculated over the total scores obtained from the evaluations of both experts. Krippendorff alpha is used to determine the conformity between raters as a conformity statistic and the alpha value higher than 0.80 indicates high conformity (Krippendorff, 1995). The value obtained in this study was found to be 0.88 . In this context, it can be said that there is a 
high level of conformity among the evaluators. It was thought that the narrative listening text in the 4th-grade class textbook titled "The King's Golden-Haired Daughter" and informative listening text titled "Snowflakes" were suitable to be used in applications. On the other hand, the reading text titled "The Voice of Our Heart" in 4th-grade Turkish textbook, prepared by Ada Publishing and approved by the Ministry of Education, was selected as sample text in order to prepare the students for the method of thinking out loud. Also, the texts were not selected from the textbooks taught in the school where the practice was carried out. In this way, students experienced the texts for the first time during practice.

\subsection{Data Collection}

In the application phase of the research, it is briefly explained to the students individually the purpose and content of the interview. Then, a sample application was made with the preparatory text in order to explain the course of the application. The individual interviews in two sessions lasting approximately 15 minutes were conducted with each student at the school, which they are attending. One of these sessions was informative while the other was narrative. The texts to be listen are divided into segments according to the units of meaning and each divided segment is written on a separate card. The sections on the card presented to the students were read by the researcher. Later, students were asked to voice their thoughts about division, which they listened. The voice recorder was used to record what the students listen and what they thought and understood from the section they listen. Students, who have difficulty expressing thoughts in a loud voice, have been encouraged in this regard. They were inspired to express themselves. When the application was over, the process was terminated after thanking the students.

\subsection{Data Analysis}

When the data obtained from the interviews were examined, the voice recordings were analyzed and transferred to the computer environment. In the analysis of the data descriptive analysis techniques were used. In order to reveal the strategies used in relation to the research problem and to use the collected data accordingly, the descriptive analysis was used for searching answers to "what" question.

The operations which in descriptive analysis process:

$>$ To put data of the think-aloud on paper

$>$ To make strategy list

$>$ To describe strategies used by students

$>$ To determine strategy types and frequency of strategies used

Three diverse experts examined the themes determined within the scope of the research and the reliability analysis between the coders was carried out. For this analysis, following formula was used: Reliability between encoders = ([Consensus / (Consensus + Dissensus)] X 100 (Miles and Huberman, 1994) and the reliability between the encoders were calculated as $88 \%$.

\section{Findings}

Descriptive analysis was used to determine the strategies of comprehension, which the students use during the listening comprehension process. For this, a pre-determined reading-comprehension strategy list was created. These strategies have been grouped into two groups: semantic and linguistic, using the data of various studies (Block, 1986; Pritchard, 1990; Davis and Bistodeau, 1993; Çetinkaya, 2004). While semantic strategies are based on the content of the material and the reader's background knowledge, linguistic strategies are the types of strategies, in which the meaning is achieved by differentiating the structural features of the text. The definitions and examples of these strategies that students use in their reading comprehension process are presented in table below. 
Table 4. Strategy Types, Definitions and Examples

\begin{tabular}{|c|c|c|c|}
\hline $\begin{array}{l}\text { Strategy } \\
\text { Types }\end{array}$ & Strategies & Definition & Example \\
\hline & $\begin{array}{l}\text { Guessing } \\
\text { Meaning }\end{array}$ & $\begin{array}{l}\text { Guessing what to expect in the } \\
\text { subsequent parts of the text }\end{array}$ & $\begin{array}{l}\text { "Rejuvenation medicine may also be in the water. } \\
(S 2)\end{array}$ \\
\hline & $\begin{array}{l}\text { Make } \\
\text { Inference }\end{array}$ & $\begin{array}{l}\text { Reaching a conclusion by } \\
\text { benefiting from limited clues in the } \\
\text { text. }\end{array}$ & $\begin{array}{l}\text { "So, in reality snowflake cannot tell what it has } \\
\text { experienced." (S1) }\end{array}$ \\
\hline & $\begin{array}{l}\text { Using } \\
\text { Background } \\
\text { Knowledge }\end{array}$ & $\begin{array}{l}\text { Taking advantage of background } \\
\text { knowledge and experience to } \\
\text { explain the content }\end{array}$ & $\begin{array}{l}\text { "For example, there is a plant in the cave that } \\
\text { they can make antidote from that. You know, it } \\
\text { happens in cartoon movies; they find an antidote. } \\
\text { Just like that." (S2) }\end{array}$ \\
\hline & Personalizing & $\begin{array}{l}\text { Adapting the meaning of the text to } \\
\text { a person }\end{array}$ & $\begin{array}{l}\text { "Pamukkale's water may have cured the girl. I } \\
\text { have also been there. Its water is very useful. " } \\
\text { (S4) }\end{array}$ \\
\hline & Visualization & $\begin{array}{l}\text { Thinking about the meanings of the } \\
\text { text by creating cognitive images }\end{array}$ & $\begin{array}{l}\text { "Snow has come to my mind, on a winter day. } \\
\text { Children are playing snowball outside. } \\
\text { Something like that." (S3) }\end{array}$ \\
\hline & Reacting & $\begin{array}{l}\text { Demonstrating feelings according } \\
\text { to the content of the text }\end{array}$ & $\begin{array}{l}\text { "He is also helping the villagers. I never heard } \\
\text { the tale of a King who helped his village. Nice." } \\
\text { (S1) }\end{array}$ \\
\hline & $\begin{array}{l}\text { Asking } \\
\text { Questions }\end{array}$ & $\begin{array}{l}\text { Asking yourself questions about the } \\
\text { information in the text }\end{array}$ & $\begin{array}{l}\text { "That cannot be. If that hot water flows more, } \\
\text { how will they protect the surrounding things from } \\
\text { this water?" (S2) }\end{array}$ \\
\hline & Summarizing & $\begin{array}{l}\text { Retelling the information obtained } \\
\text { during listening by referring to the } \\
\text { outline }\end{array}$ & $\begin{array}{l}\text { "I think this story tells the tale of the cycle of } \\
\text { snow and the hand of friendship." (S2) }\end{array}$ \\
\hline & Evaluating & $\begin{array}{l}\text { Considering the feelings and } \\
\text { thoughts of the text in a critical way }\end{array}$ & $\begin{array}{l}\text { "The story is a little different. Actually, it could } \\
\text { have been longer. It seems like some parts are } \\
\text { missing in this way. For example, the girl was } \\
\text { saved but later that illness infected other people. } \\
\text { Everyone consumed water by coming here. } \\
\text { Humans could not escape the illness. It could } \\
\text { have ended this way." (S2) }\end{array}$ \\
\hline : & $\begin{array}{l}\text { Monitoring } \\
\text { (follow up) }\end{array}$ & $\begin{array}{l}\text { Evaluating whether you understand } \\
\text { the text, controlling the } \\
\text { comprehension process }\end{array}$ & $\begin{array}{l}\text { "Oh, I have learned something new. The } \\
\text { raindrops that I think of are lighter. Because } \\
\text { snowflakes are frozen, I thought they were } \\
\text { heavier but snowflakes area lighter." (SI) }\end{array}$ \\
\hline \multirow[b]{4}{*}{ 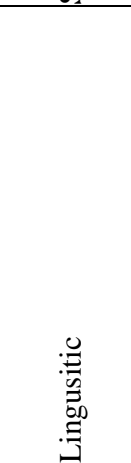 } & $\begin{array}{l}\text { Analyzing } \\
\text { Expression }\end{array}$ & $\begin{array}{l}\text { Splitting a paragraph or sentence } \\
\text { into pieces to reach meaning }\end{array}$ & $\begin{array}{l}\text { "Maybe it refers to the color of the hair while } \\
\text { saying golden hair. Meaning, the king had a } \\
\text { blonde daughter." (S1) }\end{array}$ \\
\hline & $\begin{array}{l}\text { Expressing an } \\
\text { Idear with } \\
\text { Different Words } \\
\end{array}$ & $\begin{array}{l}\text { Re-expressing content with other } \\
\text { words so that the meaning remains } \\
\text { the same }\end{array}$ & $\begin{array}{l}\text { "So they all became snowflakes like bird, fell on } \\
\text { the ground as snowflake." (S4) }\end{array}$ \\
\hline & $\begin{array}{l}\text { Identifying } \\
\text { Stereotyped } \\
\text { Words }\end{array}$ & $\begin{array}{l}\text { Finding meaning that idioms and } \\
\text { proverbs have won in sentence in } \\
\text { order to create meaning in the text }\end{array}$ & $\begin{array}{l}\text { "The sentence 'I am unable to contain myself' } \\
\text { means, as I said, I am very excited and I can't } \\
\text { control myself anymore, I want to go } \\
\text { everywhere." }(S 2)\end{array}$ \\
\hline & $\begin{array}{l}\text { Solving } \\
\text { Vocabulary } \\
\text { Problems } \\
\end{array}$ & $\begin{array}{l}\text { Using context, synonyms or similar } \\
\text { ways to find out what the word } \\
\text { means }\end{array}$ & $\begin{array}{l}\text { "So the hot spring mentioned is a place like } \\
\text { pool." (S3) }\end{array}$ \\
\hline
\end{tabular}

As observed in the table, 14 strategies have been identified when analyzing the verbal data obtained from the students using the thinking aloud method. 10 of them were included in the semantic, and 4 of them were included in the linguistic strategy group. In addition, while students were listening texts, they did not use the strategies of compensating, recognizing text structure and finding the main idea among the semantic strategies. Also they did not use the strategies of questioning the meaning, reacting to the linguistic features and skipping the unknown words which are classified among the linguistic strategies. On the other hand, the frequency of use of the strategies used by the students in the comprehension process according to the text types is given in the frequency table below. 
Table 5. Frequency Table of Strategies Used in Narrative and Informative Texts

\begin{tabular}{|c|c|c|c|}
\hline $\begin{array}{l}\text { Strategy } \\
\text { Types }\end{array}$ & Strategies & $\begin{array}{l}\text { Narrative } \\
\text { Text }\end{array}$ & $\begin{array}{l}\text { Informative } \\
\text { Text }\end{array}$ \\
\hline \multirow{10}{*}{ Semantic } & Guessing Meaning & 19 & 5 \\
\hline & Make an Inference & 15 & 22 \\
\hline & Using Background Knowledge & 6 & 3 \\
\hline & Personalizing & 4 & 2 \\
\hline & Visualization & - & 1 \\
\hline & Reacting & 7 & 12 \\
\hline & Asking Questions & 1 & - \\
\hline & Summarizing & - & 1 \\
\hline & Evaluating & 1 & - \\
\hline & Monitoring (follow up) & 1 & 2 \\
\hline \multirow{5}{*}{ Lingusitic } & Analyzing Expression & 2 & - \\
\hline & $\begin{array}{l}\text { Expressing an Idea with Different } \\
\text { Words }\end{array}$ & 4 & 17 \\
\hline & Identifying Stereotyped Words & 1 & 1 \\
\hline & Solving Vocabulary Problems & 3 & - \\
\hline & Total & 64 & 66 \\
\hline
\end{tabular}

When table 5 is examined, it is observed that students prefer semantic strategies while listening both types of text. This demonstrates that students are striving to comprehend the text with their existing knowledge. In other words, the students were more likely to use a reading model (the deduction method), according to which they keep on predicting. It is possible to state that the students are less likely to use the model (induction method), which formulates the meaning by analyzing the linguistic structures of the letters, words, and phrases since the students do not have a habit of listening to the linguistic features of the texts during listening. In addition, the most commonly used strategy in both types of texts was the strategy of inference. Accordingly, the students infer in order to comprehend the expression and meaning in the texts they listen. Listeners, when inferring, reach a conclusion with their background knowledge and past experience. In this case, it can be said that the meaning derived from the inferences of the students may differ. On the other hand the students use almost equal number of strategy when comprehending the sense of narrative and informative texts. Because of that the students have more knowledge and experiences in both narrative texts and informatice texts. Thus students have deal with many listening text since they are familiar with them in pre-school period. On the other hand, linguistic strategies have been used more often in informative texts by students. It can be argued that this is caused by the linguistic difficulties of informative texts. Students tended to use linguistic strategies in order to overcome these challenges.

In addition, the frequency of strategy use for the successful and unsuccessful listeners is shown below.

As observed in Table 6, it has been determined that students who are described as successful listeners use more strategies in the listening comprehension process. However, boy and girl students used same amount of comprehension strategies when listening $(\mathrm{S} 1=44, \mathrm{~S} 2=43, \mathrm{~S} 3=23, \mathrm{~S} 4=20)$. Accordingly, it can be assumed that successful listeners use the strategies more practically in the listening comprehension process, but no difference is observed in the use of strategy according to gender. On the other hand, it can be argued that the linguistic strategies are used by the students who are considered as unsuccessful listeners because of the difficulties in recalling the words and sentences during listening.

Table 6. Frequency Table of Strategies Used by Successful and Unsuccessful Listeners

\begin{tabular}{|c|c|c|c|c|c|}
\hline \multirow[t]{2}{*}{ Strategy Types } & \multirow[t]{2}{*}{ Strategies } & \multicolumn{2}{|c|}{ Successful Listener } & \multicolumn{2}{|c|}{ Unsuccessful Listener } \\
\hline & & S1 & S2 & S3 & S4 \\
\hline \multirow{10}{*}{ Semantic } & Guessing Meaning & 7 & 2 & 7 & 8 \\
\hline & Make an Inference & 18 & 16 & 1 & 2 \\
\hline & Using Background Knowledge & 2 & 4 & 2 & 1 \\
\hline & Personalizing & 3 & 1 & - & 2 \\
\hline & Visualization & - & - & 1 & - \\
\hline & Reacting & 8 & 11 & - & - \\
\hline & Asking Questions & - & 1 & - & - \\
\hline & Summarizing & - & 1 & - & - \\
\hline & Evaluating & - & 1 & - & - \\
\hline & Monitoring (follow up) & 2 & 1 & - & - \\
\hline \multirow{5}{*}{ Lingusitic } & Analyzing Expression & 1 & 1 & - & - \\
\hline & Expressing an Idea with Different Words & 2 & 3 & 11 & 5 \\
\hline & Identifying Stereotyped Words & 1 & 1 & - & - \\
\hline & Solving Vocabulary Problems & - & - & 1 & 2 \\
\hline & Total & 44 & 43 & 23 & 20 \\
\hline
\end{tabular}


It has also been determined that successful listeners tend to use more likely the strategies that are important in terms of comprehension, such as prediction, inference, questioning, summarizing and monitoring (follow up). Successful listeners are more likely to overcome the challenges they encounter during listening, by using these strategies.

In addition, the strategy that the successful listeners use the most is the strategy of inferring, while unsuccessful listeners use the most is the strategy of expressing themselves in different words. This shows that successful listeners are striving to construct meaning during listening, while unsuccessful listeners are concentrating on analyzing the constructions of words and sentences.

\section{Conclusion and Discussion}

The purpose of this research is describing and comparing the listening-comprehension strategies used by the students who are identified successful and less successful about listening. Hence, the students, who attend the fourth grade of elementary school, were classified as successful and successful listeners based on certain criteria, and they applied thinking aloud method. When the data obtained from the think-aloud method was interpreted, it has been observed that the listening-comprehension strategies by used students differed. It has been determined that students who are identified as successful listeners use more strategies on their listening comprehension process. Ylldız and Kılınç (2015) argue that a good listener can decide what to listen to and how to listen; specify different listening strategies according to the types of texts.

Another result obtained in the research is that the strategy that the successful listeners use the most is the inference while the unsuccessful listeners use the expression in different words strategy. This shows that the successful listeners are more engaged in understanding the text while the unsuccessful listeners focus on the analysis of the text.

In the study, we have concluded that the students use almost equal number of strategy when comprehending the sense of narrative and informative texts. This result can be explained by the fact that the students have more knowledge and experiences in both narrative texts and informatice texts. Thus students have deal with many listening text since they are familiar with them in pre-school period.

On the other hand, linguistic strategies have been used more often in informative texts by students. This result can be explained by the low level of familiar concepts and density that the informative texts contain in their structure (Crowe, 2007). Students tended to use linguistic strategies in order to overcome these challenges.

Another result of the survey is that the successful listeners are more likely to use the strategies of guessing the meaning, inferring, answering questions summarizing and monitoring, which are recommended by many sources as main listening-comprehension strategies. Successful listeners have used these strategies, along with their previous information and interpretation strength to understand text even though they have not used these strategies consciously. In fact, prediction and inference are automatically used in the comprehension process, constantly thinks about what happens in the subsequent part of the text and consolidate the pieces (Özenici, Kınsız, and Seçkin, 2011). On the other hand, the students in both groups did not prefer to use the strategies of finding the main idea among the strategies that were considered significant in terms of comprehension. As stated in the study of Ateş (2011), this result supports the fact that less time is devoted to studying of finding the main idea in the schools.

The results of the study show that students use various strategies in the process of comprehension, but the competences of the students to evaluate their own comprehension are very low. This prevents to achieve the goal of listening comprehension.

From this point of view, we should focus on teaching activities aiming to improve students' comprehension skills, especially in the first years of primary school. Listening strategies which are implemented in a planned way, can be help learners' performance and self-learning skills. In this regard, teachers need to be aware of the variables in the listening comprehension process and the role they are supposed to undertake. Thus, we recommend training the teacher candidates in the use of strategy in the process of teaching listening. On the other hand, we hope that the self-regulation skills of the individuals will be improved together with the improvement in the high-level listening comprehension by the increasing number of teachers, who uses the appropriate strategies and model these strategies in teaching.

\section{References}

Akyol, H. (2010). Turkish teaching methods appropriate to the new program ( ${ }^{\text {rd }}$ edition). Ankara: Pegem Akademi Publications.

Ateş, S. (2011). Evaluation of fifth-grade Turkish course learning and teaching process in terms of comprehension instruction. Unpublished doctoral dissertation, Gazi University, Ankara.

Bialystok, E. (1981). The role of conscious strategies in second language proficiency. The Modern Language Journal, 65(1), 24-35.

Block, E. (1986). The comprehension strategies of second language readers. TESOL Quarterly, 20(3), 463-494. https://doi.org/10.2307/3586295 
Crowe, D. A. (2007). Reading comprehension instruction in the middle grades for students with learning and behavior problems. Unpublished doctoral dissertation, Auburn University, Alabama.

Çetinkaya, G. (2004). An applied study on reading-comprehension strategies: Observations about the reading process in mother tongue and foreign language. Unpublished master's thesis, Gazi University, Ankara.

Davis, J. N., \& Bistodeau, L. (1993). How do L1 and L2 reading differ? Evidence from think aloud protocols. The Modern Language Journal, 77(4), 459-471. https://doi.org/10.1111/j.1540-4781.1993.tb01993.x

DeVellis, R. F. (2003). Scale development ( $2^{\text {nd }}$ edition). California: Sage Publication Inc.

Ergin, A., \& Birol, C. (2000). Communication in education. Ankara: Anı Publications.

Glesne, C. (2011). Becoming qualitative researchers ( $4^{\text {th }}$ edition). Boston: Pearson Education.

Güneş, F. (2012). Think-aloud in education. Journal of Academic Studies, 55, 83-104.

Kline, P. (1986). A handbook of test construction: Introduction to psychometric design. New York, NY, US: Methuen.

Krippendorff, K. (1995). On the reliability of unitizing continuous data. Social Methodolgy, 25, 47-76. https://doi.org/10.2307/271061

Miles, M. B., \& Huberman, A. M. (1994). An expanded sourcebook-qualitative data analysis (2 ${ }^{\text {nd }}$ edition.). London: Sage Publications.

Milli Eğitim Bakanlığı Eğitimi Araştırma ve Geliştirme Dairesi Başkanlığı (2003). Uluslararası okuma becerilerinde gelişim projesi-PIRLS 2001 ulusal rapor. Ankara: MEB.

Milli Eğitim Bakanlığı Eğitimi Araştırma ve Geliştirme Dairesi Başkanlığı (2010). Uluslararası öğrenci değerlendirme programı-PISA 2009 ulusal ön raporu. Ankara: MEB.

Milli Eğitim Bakanlığı Ölçme, Değerlendirme ve Sınav Hizmetleri Genel Müdürlüğü (2015). Uluslararası ögrenci değerlendirme programı-PISA 2012 araştırması ulusal nihai raporu. Ankara: MEB.

O'Malley, J. M., Chamot, A. U., \& Kupper, L. (1989). Listening comprehensions trategies in second language acquisition. Applied Linguistics, 10(4), 418-437. https://doi.org/10.1093/applin/10.4.418

Onan, B. (2005). The function in developing of understanding skills (reading/listening) of language forms in Turkish teaching of secondary education (6th, 7th and 8th graders in primary schools). Unpublished doctoral dissertation, Gazi University, Ankara.

Özenici, S., Kınsız, M., \& Seçkin, H. (2011). Çıkarımda bulunma becerisi ve çıkarımların okuma- anlama sürecindeki işlevi. Uluslararası Insan Bilimleri Dergisi, 8(1), 1665-1681.

Patton, M. Q. (2002). Qualitative Research \& Evaluation Methods ( $3^{\text {rd }}$ edition). Sage Publications, Inc.

Pritchard, R. (1990). Cultural schemata and processing strategies. Reading Research Quarterly, 25(4), 273-295. https://doi.org/10.2307/747692

Someren, M. W., Barnard, Y. F., \& Sandberg, J. A. C. (1994). The think aloud method: a practical guide to modelling cognitive processes. London: Academic Press.

Stake, R. (1995). The art of case study research. Thousand Oaks, CA: Sage.

$\mathrm{Su}, \mathrm{Y}$. (2002). On the teachability of listening learning strategies to Chinese EFL learners at the beginning level. Unpublished master's thesis, Guangdong University of Foreign Studies.

Tüzel, S. (2013). Effects of classroom background noise on cognitive performance of listenıng process in secondary school students. Journal of Theory and Practice in Education, 9(4), 363-378.

Umagan, S. (2007). Listening. In A. Kırkkılıç, H. Akyol (Eds.), Turkish teaching in primary education (pp. 149-163). Ankara: Pegem Akademi Publications.

Yıldız, N., \& Kılınç, A. (2015). Effects of teaching listening strategies to listening comprehension skils level in the fifth grade students. Erzincan Üniversitesi Sosyal Bilimler Enstitüsü Dergisi, 8(2), 17-34.

\section{Copyrights}

Copyright for this article is retained by the author(s), with first publication rights granted to the journal.

This is an open-access article distributed under the terms and conditions of the Creative Commons Attribution license which permits unrestricted use, distribution, and reproduction in any medium, provided the original work is properly cited. 